\title{
Empty space or sacred place? Place and belief in social work training
}

\section{Greta Galloway $^{1}$, Pat Wilkinson ${ }^{2}$, and Gavin Bissell ${ }^{2}$}

Summary: This paper highlights common errors in social work students' approaches to faith/spirituality and place whilst on field education placement. It briefly investigates the Christian conception of sacredness and space which often underpins such errors.

The issue is exemplified by contrasts between Aboriginal Australian conceptions of place and spirituality and the mutually exclusive conceptions of these spaces, held by many non-Aboriginal welfare practitioners in Australia. This paper suggests some ways in which social workers, including social work students, could engage with spirituality, inclusive of geo-socio-political materiality, in their work, where appropriate, with Indigenous, migrant, refugee or colonial settler populations.

The paper engages critically with literature on cultural competence in relation to issues of land, and the identity one gains from connection to land, and spirituality. This paper concludes by identifying key questions for placement students and educators seeking to respond appropriately when interfacing sacred spaces of the 'other'.

Keywords: space; Christianity; Aboriginal spirituality; cultural competence

1. Clinical Director, Alan Webster Consultancies greta.galloway@iig.com.au

2. Head of of Dept of Social Sciences and Humanities. University of Bradford, UK

3. Lecturer in Social Work, University of Bradfor

Address for Correspondence Dr Gavin Bissell, Department of Social Sciences and Humanities, University of Bradford, Richmond Road, Bradford, BD7 1DP, g.bissell@bradford.ac.uk

Date of publication: 26th October 2009

28 Journal of Practice Teaching \& Learning 8(3) 2008, 28-47. DOI: 10.1921/146066909X478262. @ wE-b 


\section{Introduction: Place and belief as an aspect of human geography in social work}

Interest in the significance of place in social work has been inconsistent. Some areas of provision show a higher level of interest in place than others, but on the whole there seems to have been relatively limited interest in place, perhaps reflecting the primary focus of social work upon human relationships rather than upon the geographic location in which they occur (Wilkinson \& Bissell, 2005).

Even so, in recent research, both Milligan(2003) and Conradson (2003) have highlighted the importance of place in social work, whilst Segrott \& Dowell (2004) have looked at 'obsessive compulsive perceptions of space', and Johnson, Cloke and May (2005) have studied the exclusion of homeless people from areas of the city of London. Nonetheless, given the limited research interest in social work and place, it might initially appear unreasonable to focus upon the relationship between landscape and belief in social work. Why is it important?

The relationship between place and belief is important because it underpins some common errors made by social work students on placement. In this article, we examine some of these errors, focusing in particular upon a case study example of social work with Aboriginal Australians. We argue that the cultural competence approach to belief in social work, moreover, tends to overlook perceptions of place and their significance to service users. Finally, we suggest an enlarged conception of cultural competence, which critically incorporates elements of cultural anthropology as exemplified through the Aboriginal Australian case study.

The relationship between land and belief systems is conceived in two primary ways in literature. The first of these conceptualisations suggests that places of themselves induce particular patterns of thought leading to the development of whole belief systems. Thus Allan \& Warren (1993), Eaton(1994), Baudrillard (1986), and others, noted that the origins of many of the world's religions occurred in wilderness areas. They suggested that this landscape, existing as it does at the geographic edge of the human community, induces in people a process of anxiety and questioning of the human condition, giving rise to particular belief systems.

A second idea of the relationship between land and belief is that,

29 Journal of Practice Teaching \& Learning 8(3) 2008, 28-47. DOI: 10.1921/146066909X478262. @ w\&bb 
as part of their ontology, belief systems hold particular assumptions/ perceptions of place. So for example Baudrillard (1986) implies that there is an American 'sect' mindset, a sort of eternal 'Plymouth Rock' outlook, in terms of which wilderness is seen as pure landscape or 'promised land,' waiting for the construction of the optimum society. The land is available to people to reconstruct as a resource for the fulfilment of their needs (whether these be temporal or spiritual).

Other belief systems perceive landscape as filled with invisible beings, providing the individual with an inner map or sense of direction that situates her/him in space. Siberian Khanty, for example perceive landscape in this way. Jordan (2003) articulated how a belief system orients the Khanty in space, filling out the directions of above, below, before, behind and to either side with meaning.

Regardless of this literary discussion about landscape itself leading to the production of particular beliefs or the ontological assumptions about landscape held within belief systems, a conclusion can be drawn that there is an interactive relationship between people and their physical environments (place) which contains spiritual/ontological aspects (belief). This paper is concerned with the effect of belief upon place, and its consequences for social work.

\section{The effect of belief upon place}

A key distinction can be made between places formally linked to belief systems (for example churches and some other holy sites), and places that are perceived to be of significance for the identity of an individual in connection with his or her beliefs. For example Jackson (1995) studied Mormon attitudes on pilgrimage and distinguished between sites to which access was restricted to believers, notably temples in the case of Mormons, and sites which were important to the maintenance of belief and of individual identity of believers. These two types of place can conveniently be referred to as 'sanctified' and 'sacred' respectively, and it can be argued that social workers are more likely to encounter difficulties with the latter, because they are less visible. The links between formally sanctified places and power often take the form of restriction of access, and this is usually more visible. For example, Stevenson (2006) studied access to ancient temples, and

30 Journal of Practice Teaching \& Learning 8(3) 2008, 28-47. DOI: 10.1921/146066909X478262. @ w\&-b 
social status. At the same time, access to 'sacred' places can be restricted by property rights, and this is less visible.

The belief -specific character of 'sanctified' places can be illustrated by a Christian example. Altenberg (2003) researched the early spread of churches in Scandinavia, and asked if they did not begin to enclose sanctified spaces and exclude profane space as an attempt to redefine sacred spaces within a pagan landscape. The philosopher Aldous Huxley, travelling within South America in the early 1930s, noted the 'crowded' nature of consecrated church interiors resulting from this sharp division between sanctified and profane space. They seemed to him half - filled with memorials and human remains (Huxley, 1934), as if everything considered sacred must be contained within the confines of sanctified space.

Similarly, the writer Graham Greene, travelling in Zapatist Mexico in the late 1930s, referred to the 'Godless' character of the landscape in which churches were demolished, a landscape in which men are 'without hope', and 'die like dogs' (Greene, 1939). Greene suggested that the landscape was made Godless through the demolition of personmade sacred space, implying that the landscape of itself is a profane space made sacred only through the erection and sanctification of 'churches'. This widespread Christian view of the relationship between landscape and belief has also been noted by human geographers (for example, Muir, 2000).

A contentious example of the Christian perception of space was offered by the philosopher Baudrillard. In his controversial analysis of American culture, Baudrillard (1991) argued that the Puritan settler perception of the American deserts as 'empty' spaces, in which to build a religious utopia, led to the massacre of the Indigenous population. This has been a feature of many settler societies, including that of Australia which will be referred to later in this article.

We now have the outlines of some aspects of a Christian perception of place. These are: that particular places are made sacred through belief systems and sanctification separating the profane from the sacred; that landscape is available as a resource to people in order for them to meet their sacred and temporal needs; and that landscape is empty until it is harnessed, contained and controlled by persons. It is therefore now appropriate to consider some errors to which this perception of space can lead. A suitable place to start is perhaps Park's (1799) error, and his consequent misunderstanding of Mosques.

31 Journal of Practice Teaching \& Learning 8(3) 2008, 28-47. DOI: 10.1921/146066909X478262. @ wEb 
The explorer Mungo Park visited East Africa in the 1790's, and thought that the mosques he saw there were not proper mosques, because they were roofless or lacked complete boundary walls. This perception suggests that he thought of them as churches, enclosing a sanctified space.

Social work students and teachers have made similar errors about the physical proximity of a mosque to a placement, presuming it to be a place of worship somewhat like a Christian church, to which Muslims would automatically go to pray (Wilkinson \& Bissell, 2005). However, as Eaton (1994) has pointed out, Muslims may pray anywhere, the Earth itself being sacred.

Another popular yet erroneous notion exposed by Van Poperin (2004) was that Muslim women in Britain remain at home and avoid the public realm for religious reasons. When Van Poperin (2004) asked Muslim women about this, however, she found that the reasons were connected with gender relations and were not primarily religious.

For reasons also relating to the use of incorrect assumptions about place, Eck (1998) thought that Hindu community organizations are misunderstood because their geographic relationship to India is misunderstood. She noted how Hindu community associations in Britain reconstruct geographic regions in India. This is because occupational groups that have a shared family name are concentrated in specific geographic regions of India, and these community groups are reconstructed in the new home space of Britain. Social workers, however, sometimes assume that Hindu community organizations are for all Hindus.

Both the Muslim and Hindu examples above illustrate the fact that social workers, when working in neighbourhoods or with families who designate themselves as, or who are designated by others as, Muslim or Hindu, may be inclined to reduce all issues and relationships to the sacred/religious realm, and then on top of this, operate inappropriately Christian assumptions. Since white, Western capitalist democracies pride themselves on the theoretical separation of state and church, these same errors are not made when working with Christian families. Rather, we would suggest that, in the latter case, and despite the irony of the social itself being imbued with Judeo-Christian ethics and morality, spiritual aspects are overlooked entirely within Christian families since social work itself is a profession which is used to implement the programs and social legislation of the (profane) state.

32 Journal of Practice Teaching \& Learning 8(3) 2008, 28-47. DOI: 10.1921/146066909X478262. @ w\&bb 
An interesting example in this regard is brought to light by a critical reading of some writings of the essayist William Hazlitt, together with those of the Nonconformist divine John Bunyan (1904). Hazlitt (1841) referred to the characteristic relationship to place of Nonconformists as 'in this world but not of it'. In this 'pilgrim' perspective, life is seen as a journey, upon which the believer gathers as few possessions as are necessary. This is because it is believed that one carries the things of value, one's true worth, within one. Privacy and simplicity in the home environment or in residential placement are consequently key aspects of belief. A care-plan, for example, emphasizing social support and entertainment facilities in the environment with such Christian persons, would probably miss its target. Moreover, there are instances of home frugality being misunderstood, and consequently wrongly assessed, as evidence of deprivation or self neglect. This can be another error, then, of a culturally ill-informed social worker.

In the following section, a case study of Aboriginal Australian spirituality is presented as an example of the primacy of land to belief systems and as the basis of social, political and economic relationships of people to each other. This example illustrates the value of social workers engaging with cultural anthropology as a discipline, to establish rapport, to plan, and intervene, and to evaluate practice. While this may appear an extreme example of social work consideration of place and belief, it is in the extreme that the socio-economic, psychological/spiritual and political importance of place to service users can be seen most clearly.

\section{Case Study. Aboriginal Australia: Interface with land, spirituality and social work}

Nowhere else in the world does the colonial notion of land as 'empty space' stand in such sharp contrast to the notion of 'sacred place', than in the relationship between Aboriginal and non-Aboriginal Australia. Not until 1992, with the High Court judgement in the case known as Eddie Mabo and others $v$ The State of Queensland was the notion of terra nullius (land of no-one at the time of colonial occupation), overturned (Brennan, 1993). For the first time in the nation's history, Australia acknowledged the unique relationship of Aboriginal people to the land. Largely this High Court judgement was argued and won on the basis

33 Journal of Practice Teaching \& Learning 8(3) 2008, 28-47. DOI: 10.1921/146066909X478262. @ wEb 
of demonstrable Aboriginal spiritual connection to land (Brennan, 1993), making this a case of especial significance. Furthermore, by unravelling Aboriginal spiritual beliefs in land, a study of this case reveals the fullness, the richness, and the bounty of land as it accrues to Aboriginal people in spiritual, social, economic and political terms. Finally, a study of this case provides an opportunity to explore the opportunities and challenges such knowledge of land lore (belief, myth, legend) and Law (enacted relationships of land lore) give social workers in their engagement with Aboriginal people.

To understand Aboriginal people's connections to a landscape rich in spiritual, social, economic and political sustenance, one first needs to know something of Aboriginal people's beliefs about creation and their own place within that creation. Stanner (1976), a past professor of anthropology, is renowned for work in this field. Anthropologist Charlesworth (1998) acknowledged the impact of Stanner's work on changing public perception towards Aboriginal people and on present approaches to land rights' claims. It is therefore Stanner's (1976) presentation of the commonalities in Aboriginal religious life that is examined here.

Stanner observed that commonalities in Aboriginal belief revolve around, firstly, certain myths and stories about the creation, such as that of the rainbow serpent; secondly, the concept of ,The Dreaming,; thirdly, the role of ancestor spirits who gave (and continue to give) certain clans certain rights to land, and finally, an acceptance of the notion of the sacredness of land.

\section{Myths and stories of the creation}

Stanner (1976) drew on Strehlow's writing on the Aranda people of Central Australia, to discuss the creation of earth (Charlesworth, 1998, pp. 4-5). This is précised here.

In this cosmology there were three domains: the sky, the surface of the earth and the interior of the earth. There were sky beings, but they had no interest in earth beings.

The earth was a dark, cold, desolate, featureless place with no plants or animals. But there was a form of life, all clumped together - human like, but foetal. This form of life was immobile and helpless, alive but without

34 Journal of Practice Teaching \& Learning 8(3) 2008, 28-47. DOI: 10.1921/146066909X478262. @ wEbb 
Empty space or sacred place? Place and belief in social work training

the capacity to mature, decay or die.

Beneath the surface of the earth there were mature, superhuman beings who intermixed their essential humanity with other vital life principles and forces of plants and animals. This life lay under the earth, deeply asleep. During the creation of the world in its current form, these sub terrestrial life forms spontaneously awoke and broke through the surface of the earth. The places from which they emerged are recognised by Aboriginal people as sacred sites. The sub terrestrial beings breaking through the surface of the earth at the time of this creation are the ancestral spirits of the particular group (clan/ band) of people living there. These sub terrestrial beings brought forth life and warmth in four life forms: animals which thought and acted like human beings; perfectly formed humans who could change at will into species of animals; humans who had plant affinities and finally the smallest group, human beings, who could not take on animal or plant forms. All of these life forms could feel joy, pain (etc) and age in a physical sense, and die, but a second soul in them could not die. These awakened sleepers, or ancestral beings, had super human creative capacity. They went far and wide, separating the clusters of life on the surface of the earth from each other, freeing them from their physical disabilities and separating the sexes and teaching them to live as true men and women on the earth.

When their work was done, they went into the earth or 'turned' into sacred land forms: hills, rocks, trees, and waterholes. Some went into the sky and these sky beings were interested in the affairs of the earth and were able to affect people's life on earth. The sun, moon and planets now became set in their course, but every place from which the ancestral beings had emerged was charged forever with their existence in the form of vitalistic energy. Before they finally disappeared, the ancestor spirits left behind sacred objects and composed songs, stories and ceremonies to commemorate what had happened. These were taught to the people remaining at these sites. People remaining were the descendents of these ancestor spirits and as such had particular rights and responsibilities with regard to these songs and ceremonies (lore) and to the land (Law).

\section{The Dreaming}

Sometimes this creation is referred to as The Dreamtime, yet Stanner (1976) reminds us that The Dreaming is not a time, back then, but has

35 Journal of Practice Teaching \& Learning 8(3) 2008, 28-47. DOI: 10.1921/146066909X478262. @ w\&bb 
always existed and exists in the present. This sense of time evoked through the understanding of The Dreaming is what Stanner called 'everywhen'. Beings have always pre-existed their birth event and will exist past death in the Dreamtime.

Secondly, then, and most important for the discussion of sacredness and place, is the relationship of the concept of The Dreaming to place. As Myers (1991) puts it

The Dreaming links people and place. The place from which a person's spirit comes is his or her Dreaming-place, and the person is an incarnation of the ancestor who made the place. A person's Dreaming provides the basic source of his or her identity, an identity that pre-exists (p.50).

That is, it is one's place in landscape that provides one's identity of self and relationships and responsibilities towards others. Sandra Cutts (2008) states this even more directly:

The question of identity, or who I am, is resolved in the Aboriginal consciousness by knowing the full implications of where I am(p.4).

This idea of the ongoing link of person to place, or 'everywhen', is well summarised by this quote from Riley Young, one of the leaders of the Lingara community (cited in Rose, 1998):

My lease can't wash out. No rain will wash him out him, no anything will take it away. That's mine lease. White man's lease, you read him out in the paper, you change him next year, 'nother lease. That's what they call special lease, you know, whitefella law. Mine lease you can't wash him out. He'll be there for years and years, till I die, till another man will take over that lease. Same lease. That lease forever. We call him, that lease, blackfellow law (p.110).

In this sense, one cannot own land. One is part of the land. As Stanner (1976) put it:

When an Aboriginal identifies, say, his clan-totem and its sacred site, he is not 'pointing' to 'something' which is 'out there' and 'external' to him, but 'not him': he is identifying a part of his inwardness as a human being, a part of the plan of his life in society, a condition of his placement and activity

36 Journal of Practice Teaching \& Learning 8(3) 2008, 28-47. DOI: 10.1921/146066909X478262. @ wEbb 
Empty space or sacred place? Place and belief in social work training

in a manifold of existence in a cosmic scheme. These facts are known to everyone in his community, and upheld by them as public, objective, true and valid, not just for him or just for the moment, but for everyone, everywhere at all times. According to the Aboriginal theory of 'reality', living and dead, human beings and animal beings, persons and things, persons and environment, can and do co-penetrate each other (p.18).

Human beings are part of nature, rather than above nature (Berndt, 1979). Through incarnations and reincarnations, people exist always, in various life forms. In this sense there is not separation of persons from any other life form.

\section{Ancestor spirits}

This brings us, thirdly, to the perceived role of ancestor spirits in relation to place. Not only did the ancestor spirits leave a record of what happened through the geographical landscape, but they left signs on the landscape which people could read in order to live by the law left by the ancestor spirits. People are judged, Berndt (1979) argued, not on whether they are 'good or bad', but on how much they conform to the law. Thus the practice and benefit of law requires the release of vitalistic power by the 'right' people, through the practice of ritual and ceremony on particular land sites (Stanner, 1976).

Yet conformity to Law relies upon human will or agency. Aboriginal spirituality is centred upon human will (Stanner, 1976). Thus the earth sleepers erupted to the surface of the earth through their will and returned to sleep of their will. Spirit children impregnate women or find pregnant women, and malignant spirits intervene in people's lives through their will. All the myths make a great deal about will and the conduct through which this is expressed.

Berndt (1979) focused on this notion of will, to suggest that Aboriginal frameworks of being, place more emphasis on perceiving a life journey during which people are called upon to make choices. These choices result in consequences, for the individual, for their family/clan, and for the earth. One does not therefore experience the consequences of actions in a life hereafter, but in the present. The consequences of life choices are experienced as a result of a person's adherence to the Law. The choices one makes are not judged in moral terms, but understood in

37 Journal of Practice Teaching \& Learning 8(3) 2008, 28-47. DOI: 10.1921/146066909X478262. @ wEb 
terms of their consequences. Errors or mistakes or particular 'turnings' are focused upon for their consequences with an understanding that these turnings can have positive consequences (out of badness, good can emerge; Berndt, 1979). Errors or mistakes are not focused upon in moral terms, but in terms of the learning they provide to persons about the land and their place within it.

\section{The sacredness of land}

Finally, then, Aboriginal spirituality can be seen to be formulated, not on the basis of some type of moral end state (perfection) to which people aspire, but upon a law linked to particular places. Ancestor spirits are not, therefore, perceived as gods. As Charlesworth (1998) states:

In these religious systems there are no gods: the ancestor spirits who shaped the territories or 'countries' and gave a moral and religious ceremonial 'Law' to each group 'at the beginning of things', and who impregnated particular sites with spiritual power, are certainly not gods and do not even function as moral and spiritual exemplars..... in Australian Aboriginal religions the particular land sites are the mediators of vitalistic power if they are cared for and approached in the appropriate way (p.xix-xx).

Having briefly outlined the main features of Aboriginal spirituality in its relation to land, it is now appropriate to consider the implications of this for social work practice.

\section{Significance of Aboriginal spirituality in land and social work practice}

Social Work practice in Australia is practised from the same, largely unconscious Judeo-Christian perspective of the state. This is likely to be magnified as welfare services are increasingly organised through church-run organisations. As posited earlier, connections to land from Judeo-Christian perspectives often include understanding persons as having dominion over land, rather than co-existing with land as

J Journal of Practice Teaching \& Learning 8(3) 2008, 28-47. DOI: 10.1921/146066909X478262. @ wEb 
part of an equal creation, as is the case with Aboriginal spirituality. Land has been something non-Indigenous populations have seen as something to discover, conquer, battle, resist, fear, control and to own. Nowhere are these positions to land taken more seriously than in the 'harsh', 'dangerous' landscape of Australia. Social workers will only understand Aboriginal people when they understand their ongoing and ever belongingness to particular landscapes, not as optional ways of living but as intrinsic sites of the self.

Christianity in the Australian modernist context operates from the construction of a material/spiritual binary rather than from a spirituality literally grounded within the physicality of the earth. Conversely, Aboriginal religions are, arguably, 'geosophical' in that spiritual power and wisdom is linked to places (Charlesworth, 1998). Yet, for non-Aboriginal Christians, Heaven is perceived as the realm of God and spirit, rather than earth, in all of its splendid physicality being perceived simultaneously as the realm of spirituality. This lack of dualistic analysis, however, is a hallmark of anti-oppressive welfare practice which seeks to understand people holistically, that is in terms of their bio-psycho-social-political-economic and spiritual contexts and frameworks. The above analysis of land has indicated the bio-psychospiritual connection of Aboriginal people to land. Land is also important in terms of real socio-political materiality.

Philosophies and practices of neo-liberalism, globalisation and internationalisation have resulted in people distancing themselves from a particular place or locale in order to operate as a market player within a global context. Care, concern and loyalty to place may be diminished in this context as the resources of a place are exploited for profit (Stilwell, 1997). Nonetheless, Indigenous Australians too recognise land as a resource which provides economic security (Brennan, 1993). For Aboriginal Australians this has ever been, as exemplified in the provisioning of food or items of trade from the land, or in more contemporary times of land rights, the royalties which are paid to Aboriginal groups for mining and exploration rights to land (Brennan, 1998).

Political security too accrues to people through access to land. Thus, legally recognised belongingness to land confers upon one rights of citizenship and the security this affords one in their own land or the land of others. Without land, political security is tenuous. This is true for Australian Aboriginal people who have no form of political clout

39 Journal of Practice Teaching \& Learning 8(3) 2008, 28-47. DOI: 10.1921/146066909X478262. @ w\&bb 
other than the land rights they have won through law, since Australia is the only country which has no treaty with its original inhabitants (Havermann, 1999), no reserved seats of parliament (as do the Maori in Aoteroa/New Zealand), and no body through which to elect their representatives to act on their behalf with government. It is only through land rights that pastoralists, (through the land rights ruling in the Wik case, 1996, that pastoral leases do not extinguish native title rights), miners (who seek to explore and drill for mineral resources on Aboriginal land), and government are forced to engage politically with Aboriginal people (Havermann, 1999).

Belongingness to land also contains an important emotional/ affective component. This is recognised positively through, for example, recognising the beauty and comfort (solace) of land, or in absence from land, through diaspora, the yearning for home when we are away.

Overall, then, perhaps these social, economic, political and emotional links to land are the building blocks upon which non-Aboriginal social workers can begin to build empathy with Aboriginal people. Indeed it may only be through land empathy that we will truly connect with Aboriginal Australians. Moreover, an understanding of Aboriginal spirituality in land suggests a number of practical ways of connecting with Aboriginal people in the social work relationship.

Firstly, it is important to recognize the shared history between Aboriginal people and ourselves as non-Aboriginal social workers. Part of this shared history includes the recognition of the seizure of Aboriginal land without recompense to the original inhabitants and the displacement of Aboriginal groups from their land. This open recognition of a shared historical space with its real material, social and political consequences, largely resulting from the dispossession of land, provides Aboriginal people a narrative space from which they can engage with us, as powerful First Nations people. Recognising shared history also raises social workers' awareness of the power they have in the lives of Aboriginal people.

Giving Aboriginal people the opportunity to talk about their connection with land/country and the meaning this has for them is likewise important, as is using this narrative to focus on the unique and sovereign rights of Aboriginal people, to this place, Australia, and using this acknowledgement to build political self-esteem.

Secondly, recognizing the 'everywhen' of Aboriginal people's lives and using this narrative of the Dreamtime to focus on life journeys,

40 Journal of Practice Teaching \& Learning 8(3) 2008, 28-47. DOI: 10.1921/146066909X478262. @ wEb 
pathways, song lines, tracks and points of choice rather than 'morality' (the goodness or badness of a particular course of action). This means focusing upon the consequences of people's choices in the present for their whole life journey (everywhen), and upon their understanding of the consequences of these choices within the context of Aboriginal spirituality. This life map can be used to trace relationships of obligation. Much is made within social work of the mutuality and care of Aboriginal people for each other rather than recognising these relationships of care as simultaneously relationships of shared debt, since one's care of another exacts an obligation of debt from the cared-for, towards the carer. Relationships of care/obligation are traditionally shared within particular clan groups. Once this is recognised, social workers can understand the potential impact of case management strategies which link people in communities in relationships of care, but which actually result in placing a debt upon the 'cared-for', in relation to their carer. These relationships of debt can be onerous indeed when social workers make assumptions about Aboriginal communities in terms of their 'caring disposition' without regard to proper relationships between particular Aboriginal persons.

Thirdly, linking Aboriginal people to resources which help them retrieve their life story and which may connect them back to country. Since many Aboriginal people were forcibly moved from their land into missions or settlements by government, often as children, they may not know their connections to land and kin, which places them in a position of anomie. There are now agencies (in capital cities at least), which can be used to help Aboriginal people access government files about them or their family members. Advocating the return of Aboriginal people to country at times of ritual and ceremony, and finding resources for this and for the maintenance of sacred sites, may also help, since through these society is ordered and purpose is given to life.

In doing all of these things, using skills of connection and facilitation rather than taking a leading role will be necessary when social workers recognise situations, knowledge and practices which are not theirs to participate in, as will engaging new forms of meeting and being with people (including those of ritual and ceremony) in order to help Aboriginal people regain the deeper meaning for their lives which comes from recognition of the links between land and spirituality.

41 Journal of Practice Teaching \& Learning 8(3) 2008, 28-47. DOI: 10.1921/146066909X478262. @ wEb 


\section{Difficulties in social work implementation}

It has been very difficult for Australian social workers to demonstrate their understanding of the significance of land for Aboriginal people. They are co-opted into minimising land as the primary site of psycho-social-spiritual-economic and political well-being. A primary example of this is the relatively recent (June 21, 2007) Northern Territory intervention. This intervention came about as a government 'response' to a report focused upon the abuse and neglect of children in Northern Territory Aboriginal communit ies (Anderson \& Wild, 2007). While recommendations of the report focused on addressing factors in communities which lead to abuse (such as overcrowding; lack of employment opportunities ; and lack of infrastructure in these communities), the government intervention ignored each of these structural factors, putting its energies and resources into compulsory health checks of all Aboriginal children (rather than interventions), despite health indicators being formally known through a plethora of previous reports and health data collected through government bureaucracies; cracking down on pornography and alcohol; quarantining half of all welfare payments to Aboriginal families; and most insidious of all, attempting to place all communities on five year leases, whereby government would take over the control of communities through a lease system in exchange for community infrastructure (like housing; ANTaR, 2007), and during which time governments would negotiate 99 year leases with these communities (Altman, 2007). Further, it has been intimated that the 'rent' from these leases would be paid from the royalties paid to communities for mining rights to their land (won through the courts). In other words, the rent on the lease of Aboriginal land to government would be paid by the landlord (Aboriginal people) rather than the tenant (government; Altman, 2007; Clarke, 2007). In addition, the government wanted to suspend the permit system on communities whereby Aboriginal people have control (and therefore knowledge) of who is coming into their community (ANTaR, 2007). All of this necessitated the suspension of The Racial Discrimination Act, 1975, (Boxsell, 2007) which remains suspended in the Northern Territory to the present. Many Aboriginal people (e.g. Bamblett, 2007; SNAICC, 2007) and their non-Aboriginal supporters (e.g. Botsman, 2007; Kearney, 2007) saw this as little more than another attempt at taking

42 Journal of Practice Teaching \& Learning 8(3) 2008, 28-47. DOI: 10.1921/146066909X478262. @ wE-b 
back Aboriginal land which had long been a Howard government (the immediate previous government 1998 - 2008) agenda. It is impossible to see the link between Aboriginal rights to land and child abuse, which was the long bow the government drew. Rather, commentators (Aboriginal and non-Aboriginal) suggested that child abuse was more likely to occur with removal of the permit system and that no connection could be made between child abuse and current rights of Aboriginal people to their land (Altman, 2007).

One year on from this intervention, people are becoming cynical about the intervention, given its lack of real material impact in the lives of Aboriginal people and their communities. While 600 social workers were deployed to join the police and the army in operationalising this intervention, the lack of outcomes, at a huge cost to tax payers, and to Aboriginal people in terms of their rights to self determination on their own lands, will perhaps reinvigorate social workers to remain vigilant about scrutinising government action. This is especially important in terms of undermining Aboriginal people's rights in land, even when these actions are presented in terms of being in the 'best interests of children', a target group at the core of social work professional identity, since it was this focus of protecting children which brought to social workers their unique professional niche, identity and status in Australia (Kennedy, 1985; Van Krieken, 1992).

\section{Conclusion: Problems with the cultural competence skills model approach to belief}

This case study has used the work of anthropologists, Stanner (1976), Berndt (1979) and Myers (1991) to demonstrate the connection of Aboriginal spirituality in land. It concludes that just as the High Court recognised the link of Aboriginal people's spiritual connection to land as the basis for land rights in Australia, so social workers must recognise this link in order to work with Aboriginal people from their ontological and cosmological frameworks of spirituality. Taking on board something of anthropology's recent contributions to social work, however, may mean adopting a more critical attitude towards the 'cultural competence' model within existing training.

Therefore, while the question of the transferability of an Aboriginal

43 Journal of Practice Teaching \& Learning 8(3) 2008, 28-47. DOI: 10.1921/146066909X478262. @ wEb 
social work model in any part beyond its original context is too complex a subject to be dealt with here, it may be appropriate to consider at least one theoretical obstacle to the development of a general approach to place and spirituality within British social work. In Britain, Parkinson (2000) and Cartney (2006) have noted the limitations of the competence - based learning approach in this area. Cartney notes the tendency for skills-based approaches to make knowledge an add-on appendage to skills, whilst Parkinson notes the value of the depth learning of anthropology courses, contrasting them with the modular learning-outcomes approach. Chand (2005) seems to imply that shallow understanding of beliefs might be widespread, and bigotry perhaps not far beneath the surface with some social workers. Meanwhile O'Hagan (2001) notes the need for cultural and religious geography in social work, whilst at the same time maintaining his commitment to the competence model of learning. Overall though, even the enthusiasts of depth knowledge seem to adopt a somewhat functionalist attitude to belief systems, a weakness which human geography can claim, methodologically at least, to avoid.

In short, the cultural competence approach tends to be functionalist, focussing upon learnable lists of key dates/facts, but falling short of a comprehensive understanding of belief and of abstract concepts such as that of sacred place.

Such a comprehensive understanding might enable students to ask key questions when engaging with belief and place in social work, such as: what assumptions am I making about my relationship to the client's sacred places? What assumptions am I making about my relationship to the client and 'their' world? How does a place - focused perspective about connectedness increase my options for forming relationships with clients? What issues does this create for me in terms of 'establishing boundaries' and 'maintaining confidentiality'? What ontological assumptions am I making about the nature of the world and the client's present predicament? What assumptions am I making about resolution of the presenting issue and the client's responsibility in this regard?

4 Journal of Practice Teaching \& Learning 8(3) 2008, 28-47. DOI: 10.1921/146066909X478262. @ wEb 


\section{References}

Altenberg, K. (2003) Experiencing landscapes. Stockholm: Almkvist \& Wiksell International

Allen, T. \& Warren, A. (1993) Deserts: The encroaching wilderness. London: Mitchell Beasley International

Anderson, P. and Wild, R. (2007) Little Children are Sacred. Canberra: Commonwealth Government of Australia

ANTaR (2007) Act Now. Accessed at http://www.actnow.com.au/issues/Little childrenare_sacred.aspx (19.10.07)

Altman, J. (2007) The 'National Emergency' and land rights reform: Separating fact from fiction. Briefing Paper for Oxfam Australia

Bamblett, M. (2007). Zero mention of children in NT intervention legislation. Access through AASW NQLD 15.08.07

Baudrillard, J. (1991) America. London: Verso

Berndt, R. (1979) A profile of good and bad in Australian Aboriginal religion. in M. Charlesworth (Ed.) (1998) Religious Business; Essays on Australian Aboriginal spirituality. Melbourne: Cambridge University Press pp. 24 - 45

Botsman, P. (2007) Child abuse 'more rampant in suburbs'. Accessed http://www. abc.net.au/news/stories/2007/07/06/1971866.htm 19.07.07

Boxsell, A. (2007). Profession urges Howard to look beyond 'emergency plan' for NT. Accessed http://www.lawyersweekly.com.au/articles/08/0C04E108. asp Type $=$ Category $=853$ 19.07.07

Brennan, F. (1993).Land Rights - The religious factor. In M. Charlesworth (1998; Ed.) Religious Business; essays on Australian Aboriginal spirituality. Melbourne: Cambridge University Press (pp. 142-175)

Bunyan, J. (1904) The Pilgrim's Progress. Oxford: Oxford University Press

Cartney, P. (2006) Using video interviewing in the assessment of social work skills. British Journal of Social Work, 36, 6, 827-844

Chand, A. (2005) Do you speak English? Language barriers in child protection social work with minority ethnic families. British Journal of Social Work, 35, 6, 807-821

Charlesworth, M. (1998) (ed.) Religious Business; Essays on Australian Aboriginal spirituality. Melbourne: Cambridge University Press

Clarke, J. 2007) The great Federal land grab. Canberra Times Today, 13th August. Accessed through AASW NQLD 15.08.07

Conradson, (2003) Spaces of care in the city: the place of a community drop-in centre Social \& Cultural Geography, 4, 4, 507-525

45 Journal of Practice Teaching \& Learning 8(3) 2008, 28-47. DOI: 10.1921/146066909X478262. @ wEb 
Cutts, S. (2008) Living the Dreaming: The relationship to the land for Aboriginal Australians. Accessed at http://www.bri.net.au/livingbysandra.html. 21.06.08

Eaton, G. (1994) Islam and the Destiny of Man. Cambridge: The Islamic Texts Society

Eck, D. (1998) The imagined landscape: Patterns in the construction of Hindu sacred geography. Contributions to Indian Sociology, 32; 165-188

Froude, J. (1880) Bunyan. London: Macmillan

Greene, G. (1939) The Lawless Roads. London: Heinemann

Havermann, P. (1999) Indigenous Peoples' Rights in Australia, Canada and New Zealand. New Zealand: Oxford University Press

Hazlitt, W. (1841) The Round Table: A Collection of essays on literature, men and manners. $3^{\text {rd }}$ edition, London: John Templeman

Huxley, A.(1934) Beyond the Mexique Bay. London: Macmillan

Jackson, R. (1995) Pilgrimage in an American religion: Mormons and secular pilgrimage. in D. Dubey (Ed.) Pilgrimage Studies: Sacred places, sacred traditions. Allahabad, India. The Society of Pilgrimage Studies (pp.191-208)

Johnson, S. Cloke, P. and May, J. (2005) Day centres for homeless people: spaces of care or fear? Social \& Cultural Geography, 6, 6, 787-811

Jordan, P. (2003) Material Culture and Sacred Landscape. The anthropology of the Siberian Khanty. Oxford: Roman \& Littlefield

Kearney, S. (2007). Child abuse not so easy to uncover. The Australian, October 8th. Accessed at http://www.the australian.news.com.au/ story/25197.22547850-270, 19.10.07

Kennedy, R. (1985) (Ed.) Australian Welfare history: Critical essays. Melbourne: Macmillan

SNAICC (2007) Overview of SNAICC's response to the Federal Government's emergency measures in NT. Accessed at http://www.snaic.asn.au/news/ SNAICCViewNTM.html (18.10.07)

Muir, R. (2000) The new reading the landscape. Fieldwork in landscape history. Exeter: University of Exeter Press

Naylor,S. and Ryan,J. (2002) The mosque in the suburbs: negotiating religion and ethnicity in South London Social \& Cultural Geography, 3, 1, 39-59

O'Hagan, K. (2001) Cultural Competence in the Caring Professions. London: Jessica Kingsley

Park, M. (1799/1906) Travels in Africa. London: Dent Everyman Library

Parkinson, C. (2000) Beyond Competence in Social Work Training: How are we learning? London. University of East London, Department of Human Relations

Rose, D.B. (1988) Ned Kelly died for our sins. in M. Charlesworth (Ed.) Religious

46 Journal of Practice Teaching \& Learning 8(3) 2008, 28-47. DOI: 10.1921/146066909X478262. @ wEb 
Business; Essays on Australian Aboriginal spirituality. Melbourne: Cambridge University Press (pp. 103-119)

Stanner, W.E.H. (1976) Some aspects of Aboriginal religion. in M. Charlesworth (Ed.) Religious Business; Essays on Australian Aboriginal spirituality. Melbourne: Cambridge University Press (pp. 1-23)

Stevenson .(2006) Power and Place: Temple and identity. London: Macmillan Stilwell, F. (1997) Globalisation and cities: An Australian political-economic perspective. Canberra: ANU Urban Research Program

Van Krieken, R. (1992) Children and the State: Social control and the formation of Australian child welfare. North Sydney: Allen and Unwin

Van Poperin, A. (2004) Gender, Islam and Public Participation: A case of Muslim women in Bradford. Unpublished Mphil. thesis. Bradford: Bradford university

Wilkinson, P. and Bissell, G. (2005) Social work education and the 'place' of placements. Practice, 17., 4, 28285 - 297 